\title{
O púlpito em defesa do Antigo Regime: a oratória franciscana na Corte joanina $(1808-1821)^{1}$
}

\section{William de Souza Martins ${ }^{2}$}

O artigo considera a produção oratória de cinco frades franciscanos que atuaram no Rio de Janeiro: Antônio de Santa Úrsula Rodovalho, Francisco do Monte Alverne, Francisco de São Carlos, Francisco de Santa Teresa de Jesus Sampaio e Joaquim de São José. Sob a perspectiva da linguagem religiosa que representam, os sermões dos pregadores régios referidos são analisados em particular do ponto de vista das alegorias a que recorrem e da técnica da tipologia que evidenciam a respeito do poder.

Palavras-chave: Sermões do Período Joanino (1808-1821) - Ordem de São Francisco, pregadores - Oratória Sagrada, História

The Pulpit in Defense of the Old Regime: Franciscan Oratory at the Rio de Janeiro Court (1808-1821)

The article deals with the oratorical productions of five Franciscan friars in Rio de Janeiro: Antônio de Santa Úrsula Rodovalho, Francisco do Monte Alverne, Francisco de São Carlos, Francisco de Santa Teresa de Jesus Sampaio and Joaquim de São José. From the perspective of the religious language employed, the sermons of the royal preachers are analysed, taking into special account the allegories they resorted to and the techniques of typology they show with regard to power.

Keywords: Sermons at the Rio de Janeiro Court (1808-1821) - Franciscan Order, preachers - Sacred oratory, history

\footnotetext{
${ }^{1}$ Artigo recebido e aprovado para publicação em fevereiro de 2011.

${ }^{2}$ UFRJ.
} 


\section{La chaire en défense de l'Ancien Régime : l'art oratoire franciscain à la cour de Rio de Janeiro (1808-1821)}

Cet article a pour objet l'art oratoire de cinq moines franciscains: Antônio de Santa Úrsula Rodovalho, Francisco do Monte Alverne, Francisco de São Carlos, Francisco de Santa Teresa de Jesus Sampaio et Joaquim de São José. Comme des échantillons d'un certain langage religieux, les sermons qu'ils prêchèrent sont analysés surtout du point du vue des allégories et des typologies concernant le pouvoir, auxquelles ils eurent recours.

Mots-clés: Sermons à la cour de Rio de Janeiro (1808-1821) - Ordre des Franciscains, prêcheurs - Lart de l'oratoire sacré, histoire

Não é recente o interesse da historiografia pela oratória sagrada na Corte joanina. Em 1895, José Luiz Alves publicou na Revista do Instituto Histórico e Geográfico Brasileiro um dos primeiros estudos sobre o tema. O esforço empregado pelo autor na compilação dos sermões deixou pouco espaço para análises da forma e da função desempenhadas pela produção oratória. Características semelhantes encontram-se também no artigo de Ramiz Galvão publicado na mesma revista. ${ }^{3}$ Posteriormente, os estudos adquiriram um caráter mais monográfico, ampliando-se a análise do contexto e de algumas características específicas da eloquência sagrada. Dentro dessa tendência, podem ser mencionadas as obras de frei Roberto Lopes e Maria Renata da Cruz Duran acerca do papel desempenhado pelo orador franciscano Francisco de Monte Alverne (1784-1858). ${ }^{4}$ Apesar do esforço de contextualização, tais obras carecem de análises mais profundas relativas à linguagem religiosa e política dos sermões.

Em obras de caráter mais geral, a análise da parenética do período mereceu de início um espaço pouco significativo. Assim, Oliveira Lima apenas indicava que o príncipe regente e futuro soberano cercara-se de uma "plêiade de prega-

\footnotetext{
${ }^{3}$ José Luiz Alves, “Os claustros e o clero no Brasil”, Revista do IHGB, t. LVII, parte II, Rio de Janeiro, 1895, p. 1-257; Benjamin Franklin Ramiz Galvão, “O púlpito no Brasil”, Revista do IHGB, t. 92, v. 146, Rio de Janeiro, 1922, p. 7-160.

${ }^{4}$ Fr. Roberto B. Lopes, O. F. M., Monte Alverne pregador imperial: roteiro para um estudo, Petrópolis, Vozes, 1958; Maria Renata da Cruz Duran, Ecos do púlpito: oratória sagrada no tempo de D. João VI, São Paulo, Unesp, 2010. Esta autora se ocupa particularmente da relação entre os sermões de Monte Alverne e a construção de uma identidade nacional. Em estudo mais recente, ela procurou articular a retórica com a educação. Cf. Retórica e eloquência no Rio de Janeiro, Tese de Doutorado apresentada à Unesp, Franca, 2009 (mimeo).
} 
dores que não lhe permitia nutrir saudades dos que deixara em Portugal". ${ }^{5}$ Mais recentemente, Maria Beatriz Nizza da Silva, ao analisar o Breve exame de pregadores, publicado pela Impressão Régia em 1818, assinalou algumas inter-relações existentes entre os modelos da eloquência clássica, os diversos gêneros em que se dividia a oratória sagrada e o discurso político. ${ }^{6} \mathrm{~A}$ articulação entre a parenética e a defesa da monarquia foi enfatizada por Riolando Azzi, que fundamentou sua análise em alguns sermões dos frades franciscanos Antônio de Santa Úrsula Rodovalho (?-1817) e Francisco de São Carlos (1763-1829). Nos pregadores indicados, o autor assinalou o uso figurado de monarcas do Antigo Testamento - sobretudo Davi e Salomão - para qualificar a devoção e a sabedoria política de Dom João VI. Além disso, mostrou a aplicação de metáforas orgânicas, uma prática que se tornou comum na Segunda Escolástica, para descrever as relações entre a monarquia e os súditos. ${ }^{7}$ Apesar disso, Azzi e muitos outros autores atribuíram maior relevo às ações políticas e culturais do clero quando inseridas nos movimentos liberais e da Independência. ${ }^{8}$ Kirsten Schultz estudou alguns sermões dos frades menores Francisco de Santa Teresa de Jesus Sampaio (17781830), Francisco de São Carlos e, sobretudo, do cônego secular João Pereira da Silva (1743-1818). Nessa análise pontual, a autora constatou a sensibilidade da

\footnotetext{
${ }^{5}$ Manuel de Oliveira Lima, D. João VI no Brasil, 3. ed., Rio de Janeiro, Topbooks, 1996, p. 621.

${ }^{6}$ Maria Beatriz Nizza da Silva, Cultura e sociedade no Rio de Janeiro (1808-1821), 2. ed., São Paulo, Nacional, 1978, p. 172-179. Segundo a autora, o Breve exame foi extraído da obra O pregador instruído nas qualidades necessárias para bem exercer o seu ministério, escrita pelo padre Inácio Felizardo Fortes.

${ }^{7}$ Riolando Azzi, A crise da cristandade e o projeto liberal, São Paulo, Paulinas, 1991, p. 147-160. Para a análise dos sermões, o autor se fundamentou exclusivamente na coletânea de Vicente Lustosa. Anthologia de pregadores brasileiros (Rio de Janeiro, Garnier, 1902). As informações tocantes aos anos de falecimento e morte dos oradores franciscanos foram extraídas de Wilson Martins, História da inteligência brasileira, 2. ed., São Paulo, Cultrix, Edusp, 1978, v. 2, p. 74-83. A respeito das formas de representação do poder político e, particularmente, do poder monárquico pelos teólogos e juristas da Segunda Escolástica, cf. Quentin Skinner, As fundações do pensamento político moderno, trad., São Paulo, Cia. das Letras, 1996, p. 414-460; Antonio Manuel Hespanha, História das instituições: épocas medieval e moderna, Coimbra, Almedina, 1982, p. 205-230.

${ }^{8}$ Ver, entre outros: fr. Venâncio Willeke, O. F. M., Os franciscanos e a Independência do Brasil, Rio de Janeiro, IHGB, 1981; Marina Corrêa Vaz da Silva, O pensamento constitucional de frei Sampaio (contribuição ao estudo da Primeira Constituição Brasileira), 1821-1824, Dissertação de Mestrado apresentada à USP, São Paulo, 1981 (mimeo); Gilberto Vilar de Carvalho, A liderança do clero nas revoluções republicanas (1817 a 1824), Petrópolis, Vozes, 1980; e Marco Morel, Frei Caneca: entre Marília e a pátria, Rio de Janeiro, FGV, 2000.
} 
oratória sagrada do período em relação ao desígnio providencial da monarquia lusitana que, libertando-se "como os israelitas tinham sido libertados do cativeiro do Egito", instalara-se na "Jerusalém nova", onde pôde vencer a França napoleônica ou o "monstruoso Quarto Império" do sonho do profeta Daniel. ${ }^{9}$

Saindo do âmbito das análises da oratória sagrada, nos últimos anos alguns estudiosos trataram mais a fundo da presença de imagens religiosas em outras fontes do discurso político. Para explicar a força das representações sagradas, tais análises aproximam-se da ideia defendida por Schultz, segundo a qual a conjuntura política joanina trazia uma marca simultaneamente trágica e providencial para a Casa de Bragança. As destruições e a ocupação efetuadas pelas tropas de Junot no território do Reino de Portugal contrastavam com as esperanças de fortalecimento do poder régio nos domínios americanos. Primeiramente, importa assinalar a contribuição de Lúcia Neves para o entendimento do imaginário formado em torno de Napoleão em Portugal. A autora apoiou-se nos panfletos e folhetos políticos impressos em Lisboa e no Rio de Janeiro, entre outras fontes. A partir daí, procurou analisá-las sob o ângulo dos "mitos políticos", conforme a formulação de Raoul Girardet. No período em foco, teria ocorrido na sociedade portuguesa a configuração de "constelações mitológicas", organizadas segundo a lógica das oposições binárias, tais como o Bem e o Mal, o Salvador e o representante do Anticristo, a Idade de Ouro e o Fim dos Tempos, entre outros mitos. Enquanto Napoleão era representado como castigo de Deus ou como bárbaro e incivilizado, e a França comparada à Babilônia bíblica, Portugal era visto ingressar na Idade de Ouro, sob a regência joanina. Um último aspecto a merecer destaque na obra da autora está no retorno à linguagem política do movimento da Restauração de 1640. De fato, tornaram-se moeda corrente nos panfletos políticos as referências ao Milagre de Ourique, um dos mitos fundadores da monarquia lusitana, a identificação do brasão lusitano às cinco chagas de Cristo, e outros símiles equivalentes. ${ }^{10} \mathrm{~A}$ discussão proposta por Jacqueline Hermann segue um caminho bem próximo. A emergência das crenças sebastianistas na conjuntura

\footnotetext{
${ }^{9}$ Kirsten Schultz, Tropical Versailles: empire, monarchy, and the Portuguese Royal Court in Rio de Janeiro, 1808-1821, Nova York: Routledge, 2001, p. 85-87. Tradução: Versalhes tropical: império, monarquia e a Corte Real portuguesa, 1808-1821, Rio de Janeiro, Civilização Brasileira, 2008, p. 133-136.

${ }^{10}$ Lúcia Maria Bastos Pereira das Neves, Napoleão Bonaparte: imaginário e política em Portugal (c. 1808-1810), São Paulo, Alameda, 2008, p. 94-97 e 121-182.
} 
joanina teve o efeito de reacender polêmicas em parte presentes no momento da Restauração. A autora discute particularmente as críticas veiculadas pelo letrado José Agostinho de Macedo a Vieira. Para este último, o rei desejado ou encoberto seria Dom João IV, e não Dom Sebastião, que alguns acreditavam ter sobrevivido ao fracasso da campanha na África. "Macedo afirma que a troca do rei deveu-se à 'velhacaria' de Vieira e dos jesuítas que se aproximaram do primeiro rei da dinastia de Bragança para 'introduzir-se na boa graça daquele grande Monarca." ${ }^{11}$ A mitologia política da fundação do Reino está presente também no conflito mantido entre os princípios do absolutismo monárquico cristalizados na Corte do Rio de Janeiro e as ideias contratualistas e republicanas defendidas em Pernambuco em 1817. Em uma proclamação elaborada pelo Governo Provisório, os autores argumentavam que, "no Milagre de Ourique, os lusitanos conferiram a Dom Afonso Henriques parte de seus direitos, que se transformavam, por esse ato, em obrigações do soberano. Caso o rei as descumprisse, sobre ele recaía a pena de morte ou deposição". ${ }^{12}$ No mesmo contexto, o milagre da aparição de Cristo em Ourique aparece veiculado de maneira mais convencional, isto é, garantindo a perenidade da monarquia. Em 1818, os governadores do bispado de Pernambuco publicaram uma pastoral referindo que

Jesus Cristo, filho do Deus vivo, a quem foi dado todo o poder no céu e na terra, visivelmente se deixou ver pelo nosso primeiro Rei e senhor o sempre venerável d. Afonso Henriques, e lhe disse - Eu sou o que forma os impérios e os aniquila. Quero edificar em ti e sua descendência um império para mim, para que o meu nome seja conhecido nas nações estranhas e remotas e para que conheçam os teus sucessores de que de mim recebeste o reino, as tuas bandeiras terão por brasão as minhas chagas. ${ }^{13}$

O presente artigo pretende preencher lacunas e dar sequência a algumas diretrizes esboçadas no balanço historiográfico acima. De um lado, tentará superar o caráter pontual e impressionista das análises dos sermões pregados no período joanino. Para concretizar essa proposta, duas escolhas foram necessárias. Tendo

\footnotetext{
${ }^{11}$ Jacqueline Hermann, "Dom Sebastião contra Napoleão: a guerra sebástica contra as tropas francesas”, Topoi, v. 3, n. 5, Rio de Janeiro, jul./dez. 2002, p. 108-133. A citação encontra-se na p. 123.

${ }^{12}$ Iara Lis Carvalho Souza, Pátria coroada: o Brasil como corpo político autônomo, São Paulo, Unesp, 1999, p. 70.

${ }^{13}$ Emílio Carlos Rodriguez Lopez, Festas públicas, memória e representação: um estudo sobre manifestações políticas na Corte do Rio de Janeiro, 1808-1822, São Paulo, Humanitas, FFLCH/USP, 2004, p. 189.
} 
em vista as restrições de espaço e o tipo da análise proposta, impôs-se limitar o volume da produção concionatória analisada. Do conjunto maior de 53 peças de oratória sagrada publicadas entre 1808 e 1821 no Rio de Janeiro pela Impressão Régia, foram escolhidos oito sermões da lavra de pregadores franciscanos: os frades Antônio de Santa Úrsula Rodovalho, Francisco de São Carlos, Francisco de Santa Teresa de Jesus Sampaio e Joaquim de São José. ${ }^{14}$ Os três primeiros pertenciam à província fluminense da Imaculada Conceição, enquanto o último procedia da província franciscana da Arrábida, instalando-se provavelmente no Rio de Janeiro com a Corte. Todos os oito sermões foram pregados na Corte do Rio de Janeiro. ${ }^{15}$ Para tornar mais significativo o exame da parenética franciscana no período, julgou-se pertinente acrescentar à análise seis sermões pregados entre 1808 e 1821 pelo frade menor Francisco do Monte Alverne. Estas últimas peças oratórias não foram impressas no período em pauta, sendo apenas publicadas na segunda metade do século XIX, merecendo diversas edições. ${ }^{16}$ Priorizando-se aqui a análise do núcleo franciscano de pregadores régios, espera-se posteriormente dar prosseguimento ao estudo da produção oratória do período, estendendo-a aos sermões de clérigos seculares, bispos e aos religiosos de outras ordens. Em segundo lugar, a análise aqui conduzida fundamenta-se no exame do gênero da oratória sagrada conduzido por críticos literários e filósofos da linguagem. Por fim, algumas referências teóricas ligadas à história das linguagens políticas servirão também de ponto de partida para o presente estudo.

Nos sermões, há diversas evidências da presença das técnicas hermenêuticas desenvolvidas pelos teólogos para o estudo das Escrituras. A Teologia não pode

\footnotetext{
${ }^{14}$ Os números da produção oratória foram apurados em Ana Maria de Almeida Camargo e Rubens Borba de Moraes, Bibliografia da Impressão Régia do Rio de Janeiro (1808-1822), São Paulo, Edusp, Kosmos, 1993, 2 v.

${ }^{15}$ Os oito sermões foram consultados na Divisão de Obras Raras da Biblioteca Nacional do Rio de Janeiro. Não foram consultadas as obras dos pregadores analisados disponíveis em outros acervos. ${ }^{16}$ Maria Renata da Cruz Duran, Ecos do púlpito, op. cit., p. 129-131: "Das Obras oratórias fazem parte 81 sermões, a primeira edição foi rodada na Tipografia Laemmert, dois volumes foram publicados em 1853 e outros dois em 1854. A Laemmert ainda faria mais uma edição, dessa vez com apenas dois volumes, em 1863.” Em Portugal, a editora P. Podestá publicou as Obras oratórias em dois volumes, em 1867 e 1885. No Rio de Janeiro, a Livraria Garnier publicou uma nova edição em dois volumes em 1858, acrescida de mais dois sermões e de diversas notas do próprio Monte Alverne, intituladas "Trabalhos oratórios e literários". Para o presente artigo, foi utilizada uma tiragem sem data da edição de Garnier.
} 
ser desconsiderada na análise dos sermões. ${ }^{17}$ Segundo Frye, a metáfora não constitui um ornamento no texto da Bíblia, assumindo antes uma característica diretiva na organização dos textos sagrados. Nestes, o uso da linguagem metafórica adquire funcionalidade, na medida em que se adapta à exposição de dogmas e verdades reveladas, que não poderiam ser explicados em linguagem mais descritiva. Além das características metafóricas da linguagem sagrada, Frye esclarece também o uso da tipologia como forma de retórica. O método tipológico reivindica que o Novo Testamento é chave para a compreensão do Antigo, isto é, "No Antigo Testamento oculta-se o Novo; no Novo revela-se o Antigo. Tudo o que acontece no Antigo Testamento é um 'tipo', um esboço antecipador de algo que acontece no Novo". Assim, Adão e Davi seriam tipos da figura de Cristo. Retirando significados de um processo histórico cujo final já é determinado, a tipologia "se relaciona com o futuro, e, portanto se relaciona primordialmente com a fé, a esperança e visões". ${ }^{18}$ A respeito do uso dos tipos ou figuras no discurso teológico, Auerbach esclarece que

A interpretação figural estabelece uma conexão entre dois acontecimentos ou duas pessoas, em que o primeiro significa não apenas a si mesmo, mas também ao segundo, enquanto o segundo abrange ou preenche o primeiro. Os dois polos da figura estão separados no tempo, mas ambos, sendo acontecimentos ou figuras reais, estão dentro do tempo, dentro da corrente da vida histórica. ${ }^{19}$

Ricoeur também analisa a importância do processo metafórico para a compreensão da linguagem religiosa. $\mathrm{Na}$ Bíblia, o referido processo atinge todos os discursos, de modo que não se pode falar de metáforas isoladas, mas de conjuntos metafóricos. Segundo o autor, o uso da linguagem religiosa tal como foi caracterizada se ajusta particularmente à enunciação das "experiências-limite" do homem, quais sejam, a morte, sofrimento, ódio, experiências de criação e de alegria. Visando à totalidade da vida, sob o ponto de vista do referente, e veiculando, sob o ponto de vista formal, o uso sistemático da metáfora, que abre o texto para o "exterior" ou "infinito da interpretação", o discurso religioso trans-

\footnotetext{
${ }^{17}$ Alcir Pécora, Teatro do sacramento: a unidade teológico-retórico-política dos sermões de Antonio Vieira, São Paulo, Edusp; Campinas, Unicamp, 1994, p. 20 e 42.

${ }^{18}$ Northrop Frye, $O$ código dos códigos: a Bíblia e a Literatura, trad., São Paulo, Boitempo, 2004, p. 80-113.

${ }^{19}$ Erich Auerbach, Figura, trad., São Paulo, Ática, 1997, p. 46.
} 
forma dessa maneira o discurso político: "é o 'sempre mais' que ele insinua em toda a parte, intensificando todo o projeto da mesma maneira, inclusive o projeto político" ${ }^{20} \mathrm{O}$ uso tipológico das Escrituras, bem como a construção do discurso a partir da perspectiva do fim da história, constitui características visíveis da parenética na época joanina e de outros períodos, conforme será visto adiante. Por ora, cabe ainda assinalar os quatro níveis de significação que os estudiosos da Literatura encontraram no texto bíblico, que potencializaram o uso deste na oratória sagrada. Segundo Aníbal Castro e João Adolfo Hansen, existem um sentido literal ou histórico da Escritura e um sentido místico. Este último se subdividia em três outras significações: alegórico ou eclesiológico; tropológico ou moral; e anagógico ou escatológico. ${ }^{21}$ Assim, Jerusalém pode se referir, respectivamente, à cidade dos judeus, à Igreja, à alma humana e à Cidade de Deus.

Os oradores franciscanos mencionados encontravam-se plenamente inseridos nos círculos do poder monárquico e da hierarquia eclesiástica. Assim, o mais velho dentre todos, Antônio de Santa Úrsula Rodovalho, foi eleito pregador régio e examinador da Mesa da Consciência e Ordens em 1808. Dois anos mais tarde, recebeu do príncipe regente a mercê do bispado de Angola, cargo que não chegou a exercer por motivo de doença. Em 1814, foi nomeado como censor régio. Por designação do capítulo dos religiosos da província da Imaculada Conceição, alcançou o provincialado em $1808 .{ }^{22}$ Frei Francisco de Santa Teresa de Jesus Sampaio seguiu uma carreira semelhante à de Rodovalho: em 1808, foi nomeado pregador régio e examinador da Mesa da Consciência e Ordens e, em 1813, para as funções de censor episcopal. Os religiosos da província o elegeram em 1818 para o lugar de guardião do Convento de Bom Jesus da Ilha, na baía de Guanabara. ${ }^{23}$ Quanto ao frade Francisco de São Carlos, pelo menos desde 1811 assumira as funções de pregador régio e examinador sinodal do bispado. A mesma

${ }^{20}$ Paul Ricoeur, A hermenêutica bíblica, trad., São Paulo, Loyola, 2006, p. 183-208.

${ }^{21}$ Aníbal Pinto de Castro, Retórica e teorização literária em Portugal: do humanismo ao classicismo, 2. ed., Lisboa, Imprensa Nacional/Casa da Moeda, 2008, p. 116-117; João Adolfo Hansen, Alegoria: construção e interpretação da metáfora, São Paulo, Hedra; Campinas, Unicamp, 2006, p. 103-104.

${ }^{22}$ Fr. Basílio Röwer, O. F. M., O Convento de Santo Antônio do Rio de Janeiro: sua história, memória, tradições, 4. ed., Rio de Janeiro, Jorge Zahar, 2008, p. 157-158. Os biógrafos não indicam o ano de nascimento de Rodovalho. Frei Basílio Röwer assinala que o religioso em foco iniciou os estudos no Convento de São Paulo em 1761, o bastante para torná-lo o mais experiente do grupo.

${ }^{23}$ Marina Corrêa Vaz da Silva, O pensamento constitucional de frei Sampaio, op. cit., p. 28-39, em que sistematiza os dados de Augusto Sacramento Blake, Inocêncio Francisco da Silva e de outras fontes. 
fonte revela que o frade arrábido Joaquim de São José já então se ocupava como pregador na Real Capela. ${ }^{24}$ Por fim, Francisco do Monte Alverne, o mais jovem do grupo de oradores escolhidos, foi nomeado para o ofício de pregador régio em $1816 .{ }^{25}$ Chama a atenção nesse breve perfil coletivo dos oradores franciscanos a comum ocupação do ofício de pregador na Real Capela. O trono conferia, assim, uma legitimação oficial à pregação dos frades menores, em cuja atuação, de forma complementar, podem ser constatadas a criação e a difusão de correntes de opinião e tendências políticas. ${ }^{26}$

Além da opção metodológica de reduzir o escopo das fontes, as frequentes alusões encontradas nos sermões do período joanino a passagens bíblicas e a representações religiosas similares às do movimento da Restauração de 1640 reforçam as indicações da historiografia no sentido de comparar os dois contextos, marcados pela crise e reafirmação da monarquia. A análise da parenética elaborada no período pós-filipino encontra-se muito mais desenvolvida que aquela produzida no princípio do século XIX. Entretanto, os estudos historiográficos e literários distribuem-se naquele campo de maneira desigual, devido à excepcionalidade da produção oratória do padre Antônio Vieira. No que diz respeito ao século XVII, João Francisco Marques elaborou a obra mais abrangente em termos de documentação - tendo utilizado 168 sermões, dentre os quais 153 impressos e que melhor ilumina a relação entre as representações religiosas e as aspirações políticas do período. Segundo o autor, a referida produção oratória continha fortes ingredientes propagandísticos da causa política da Restauração. O que torna mais enriquecedora a perspectiva de Marques está na análise atenta das figuras de linguagem e das representações religiosas presentes nos sermões. A história do Povo de Israel constitui o metatexto da maior parte dos sermões, na medida em que muitos pregadores estabelecem analogias entre episódios significativos do Antigo Testamento e os destinos de Portugal restaurado. Sem tentar uma exemplificação exaustiva, basta referir que o fim da dominação filipina é visto como a saída do cativeiro da Babilônia. A partir do milagre de Ourique, diversos pre-

24 "Almanaque do Rio de Janeiro para o ano de 1811", Revista do IHGB, v. 282, Rio de Janeiro, jan./ mar. 1969, p. 131 e 183.

${ }^{25}$ Fr. Roberto B. Lopes, Monte Alverne, op. cit., p. 38-39.

${ }^{26}$ Cf. a resenha de Francis Cerdan sobre a obra de Fernando Negredo del Cerro (Los predicadores de Felipe IV. Corte, intrigas y religión en la España del siglo de oro, Madri, Actas Editorial 2006, 490 p.) Criticón, n. 100, Toulouse, 2007, p. 223-224. 
gadores estabelecem linhas de continuidade entre Davi - o protótipo do governante devoto no Antigo Testamento -, Dom Afonso Henriques e Dom João IV. A causa da Restauração encontra-se legitimada por meio de tipologias bíblicas, evocando-se, por exemplo, "a visão de Daniel onde a monarquia de Nabucodonosor é apresentada simbolicamente em uma árvore alta e frondosa cujos ramos foram cortados por anjos. Estes ramos representavam as províncias e reinos que integravam o império babilônico". A partir dos referidos recursos retóricos, o pregador Cristóvão de Lisboa identificou os ramos cortados à Catalunha e ao reino português, que lutavam então pela autonomia em face da Coroa castelhana. O caráter sacralizado da monarquia bragantina e a missão providencial de que era investido o povo português transparece no mito do Quinto Império, também construído a partir de fragmentos de profetas do Antigo Testamento. ${ }^{27}$

Valmir Muraro dedicou-se a analisar em detalhes o caráter providencialista assumido pelo Quinto Império nos escritos proféticos de Antônio Vieira. A base dessa discussão está na sequência histórica de quatro reinos da Antiguidade, aos quais se seguiria "um reino que jamais será destruído, um reino que jamais passará a outro povo. Esmagará e aniquilará todos os outros reinos, enquanto ele mesmo subsistirá para sempre". ${ }^{28}$ As monarquias constantes na narrativa de Daniel foram identificadas pelo pregador jesuíta aos assírios, persas, gregos e romanos, enquanto o reino messiânico era assimilado ao povo português. ${ }^{29} \mathrm{~A}$ partir daí, operando por meio de construções de tipologias fundadas no texto bíblico, Vieira chega à conclusão de que os lusos desempenhavam o papel de povo eleito pela Nova Lei, substituindo o papel outrora ocupado pelos hebreus

\footnotetext{
${ }^{27}$ João Francisco Marques, A parenética portuguesa e a Restauração (1640-1668), Porto, INIC, 1989, v. 1 , p. $5,22,130$, e v. 2 , p. $110,118,170-171$. A comparação entre os 168 sermões relacionados por Marques à defesa da Restauração lusitana, ao longo de um período de 28 anos, realça os números significativos da produção sermonística no período joanino: como já dito, 53 peças oratórias publicadas pela Impressão Régia no Rio de Janeiro, sem contar as obras publicadas pela Impressão Régia em Lisboa, por editores particulares no Rio, na Bahia e em Portugal, e os sermões pregados entre 1808 e 1821 que depois foram publicados. A respeito da parenética em língua castelhana elaborada durante os séculos XVI e XVII, uma referência importante é a obra de Félix Herrero Salgado, La oratoria sagrada em los siglos XVI y XVII: predicadores dominicos y franciscanos, Madri, Fundación Universitaria Española, 1998, v. 2, p. 526-645. O autor atribui destaque particular aos modelos da oratória sagrada e à análise estrutural dos sermões.

${ }^{28}$ Daniel 2, 44. Cf. A Bíblia de Jerusalém, ed. rev., São Paulo, Paulus, 1995, p. 1.683-1.684.

29 “Sermão do esposo da Mãe de Deus São José” (1643). In: Sermões, Porto, Lello \& Irmão, 1951, v. VI, p. 405.
} 
no Antigo Testamento. A aparição de Cristo a Dom Afonso Henriques no Campo de Ourique conferia um caráter sacralizado à monarquia lusitana. A fundação do reino de Portugal por direta intervenção divina foi considerada por Vieira como o cumprimento das revelações proféticas de Daniel. Um dos sinais referidos por Vieira a respeito da eleição divina dos portugueses era, segundo a análise de Muraro, "a extensão do território conquistado por um reino de dimensões tão diminutas e população pouco numerosa”. Por fim, o autor analisa a abrangência espaçotemporal do Quinto Império de Vieira. Na História do futuro, o padre da Companhia de Jesus afirmou que o Quinto Império duraria "até o fim dos tempos, em substituição ao Império Romano”. Na Defesa perante o Tribunal do Santo Ofício, arguido pelos inquisidores, Vieira "mencionou um período de mil anos, seguindo-se o Reino do Anticristo. Só depois desta última etapa aconteceria o Juízo Final". Quanto à espacialidade do império messiânico, Vieira vai além das três partes do mundo conhecidas pelos antigos, incluindo também a América e "a terra incógnita agora conhecida e chamada Austral". A maior extensão territorial do Quinto Império contemplava o interesse em converter povos ainda não cristianizados. ${ }^{30}$

Apesar da importância de Vieira como modelo de oratória sagrada para os pregadores do início do século XIX, entre a segunda metade do século XVII e o período joanino interpõe-se uma série de modificações na sociedade portuguesa que alteraram a prédica sagrada. Segundo Aníbal Castro, o Sermão da sexagésima parece ter fornecido as diretrizes do que denomina "método português de pregar", vigente até o final do Antigo Regime, ainda que tenha passado por críticas e transformações. A partir das leituras de Aristóteles, Quintiliano, Cícero, dos Pais da Igreja, de frei Luís de Granada e outros, Vieira valida a divisão que os manuais

\footnotetext{
${ }^{30}$ Valmir Francisco Muraro, Padre Antônio Vieira: retórica e utopia, Florianópolis, Insular, 2003, p. 211, 215, 219, 240-241, 244, 258, 267 e 273. A respeito da identificação entre portugueses e hebreus, ver também Alcir Pécora, Teatro do sacramento, op. cit., p. 65. Nesta passagem, baseandose em Auerbach, o autor defende a ocorrência, nos sermões, de uma concepção figural dos relatos bíblicos, que permitia a Vieira estabelecer a continuidade entre o primeiro povo eleito (hebreus) e o segundo (lusitanos). A historiografia vieiriana não tem relacionado as ideias providencialistas do jesuíta a concepções semelhantes partilhadas por religiosos de outras ordens. Assim, o franciscano Gerónimo de Mendieta (1525-1604) defendia para os espanhóis o papel do povo escolhido para difundir o Evangelho a todas as partes do mundo, convertendo judeus, infiéis e gentios. John Leddy Phelan, The millennial kingdom of the Franciscans in the new world, 2. ed. rev., Berkeley/Los Angeles, University of California Press, 1970, p. 3-16.
} 
de oratória estabeleciam para a disposição do sermão: "o exórdio, a narração, a confirmação, a confutação e a peroração" ${ }^{31} \mathrm{O}$ pregador jesuíta, fiel aos modelos clássicos, para os quais o orador deveria ao mesmo tempo instruir (docere), seduzir (delectare) e pôr em movimento (movere) uma determinada audiência, condenou os exageros do cultismo e do conceptismo de outros pregadores barrocos, preocupados antes em agradar as plateias do que em ensinar a doutrina da salvação. Segundo Aníbal Castro, o próprio Vieira reconhecia não ter conseguido equilibrar adequadamente as três finalidades do discurso oratório. De fato, o padre jesuíta esteve diretamente ligado ao uso do conceito predicável, isto é, "uma sentença engenhosa tirada da Sagrada Escritura ou dos textos da Patrística, artificiosamente adaptada para servir de prova a uma determinada afirmação". ${ }^{22}$

No início do século XVIII, Dom Rafael Bluteau, frei Jacinto de São Miguel, entre outros autores, começaram a introduzir modificações na forma adotada pela oratória sagrada. Na obra de São Miguel, intitulada Arte de pregar (1739), o uso da metáfora e da alegoria é condenado em nome do raciocínio lógico. Pouco depois, sob o impacto da publicação da obra de Luís Antônio Verney, inicia-se uma polêmica em Portugal, envolvendo o modelo dominante da prédica sagrada e a renovação cultural antiescolástica associada ao Verdadeiro método de estudar. Para ficar com dois exemplos, podem ser mencionadas as obras dos fra-

${ }^{31}$ Aníbal Pinto de Castro, Retórica e teorização literária em Portugal, op. cit., p. 97. Segundo o mesmo autor, Aristóteles dividia a Retórica em cinco partes, que tratavam "da invenção, da disposição (com as subdivisões tradicionais: exórdio, narração, divisão, confirmação, confutação e epílogo ou peroração), da elocução (onde define e exemplifica os tropos e as figuras), da memória e da pronunciação" (p. 91). A respeito do filósofo grego, são elucidativos os comentários de Renato Barilli a respeito do afastamento entre a lógica e a retórica, na medida em que a primeira se fundamentava em premissas indubitáveis e a segunda partia da "opinião", isto é, "o que é aceitável por todos, pela maioria ou pelos sábios". Daí a ênfase na verossimilhança (e não na verdade) e uma certa tensão entre o conteúdo e a forma, a ciência e a arte, "atividade teórica, porque inscrita todavia no corpo logístico, mas também prática, porque agitadora das multidões que arrasta para a ação". Cf. Retórica, trad., Lisboa, Presença, 1985, p. 21-33.

${ }^{32}$ Aníbal Pinto de Castro, Retórica e teorização literária em Portugal, op. cit., p. 132. Margarida Vieira Mendes afasta-se da interpretação desse autor, na medida em que as características presentes na oratória barroca portuguesa manifestavam-se também em Castela, na Itália e em outras regiões da Europa. Tampouco concorda com o caráter programático assumido pelo Sermão da sexagésima: "não restam dúvidas de que a influência da obra oratória do padre Vieira foi decisiva a partir da segunda metade do século XVII. Todos os testemunhos são unânimes. Mas não por os pregadores se reclamarem de programas concionatórios específicos, explicitados do S. Sexagésima; antes por terem imitado a prática concionatória de Vieira". Cf. A oratória barroca de Vieira, Lisboa, Caminho, 1989, p. 178. 
des Manuel da Epifania (Verdadeiro methodo de pregar) e Manuel de Figueiredo (Palestra da oratoria sagrada), ambas publicadas em 1759. Não é casual a alusão contida no título do tratado Manuel da Epifania à famosa obra de Verney. De fato, o frade argumentava que "a perfeição e o bom gosto se atingiam através da imitação da natureza, cujos resultados se haviam de exprimir depois com uma elegância clara, sóbria e pura”. Acusava a eloquência sagrada então em voga de ter perdido a eficácia, pois a corrupção do gosto que ela própria gerara tinha habituado os fiéis "a ouvirem ornatos ligeiros, menos nobres, e pinturas impróprias à gravidade das orações sagradas". Incitava também os pregadores a pautarem-se pelo trabalho da razão, deixando de lado a imitação do sermonário tradicional, em cujo âmbito se destacava Vieira. No outro campo, frei Manuel de Figueiredo condenava a "naturalidade afetada", que julgava presente na moda francesa, defendendo o "modelo" português e os aspectos que o caracterizavam, como o estilo "elevado" e o conceito predicável. ${ }^{33}$ Não obstante a defesa do estilo barroco da oratória feita por Manuel de Figueiredo e outros, o ambiente intelectual da segunda metade do século XVIII parecia favorecer os adversários do referido grupo. Assim, nesse contexto, verifica-se a tradução para o português de diversos tratados franceses de oratória, bem como de manuais tridentinos, como os de frei Luís de Granada e de São Carlos Borromeu, arcebispo de Milão.

Passada a fase de maior contundência, a polêmica intelectual acerca da oratória sagrada parece atingir uma relativa acomodação na época da publicação das Memorias historicas do ministerio do Pulpito, de Dom frei Manuel do Cenáculo Vilas Boas, franciscano da Ordem Terceira Regular, em cuja congregação desempenhou, entre outras, a função de provincial, entre 1768 e $1777 .{ }^{34}$ Ocupando a presidência da Junta da Providência Literária, da Real Mesa Censória e da Junta do Subsídio Literário, o bispo de Beja, cuja sagração ocorreu em 1770, figurava em posição proeminente entre os defensores das reformas educacionais de Pombal. Próximo do círculo de Verney, Cenáculo empenhou-se na reforma da vida regular e dos estudos na província da Ordem Terceira Regular, particularmente o ensino do grego e do hebraico. Tais propostas encontram-se delineadas no Plano dos estudos para a Congregação dos religiosos da Ordem Terceira de S. Francisco do

\footnotetext{
${ }^{33}$ Aníbal Pinto de Castro, Retórica e teorização literária em Portugal, op. cit., p. 517-548.

${ }^{34}$ Frei Vicente Salgado, O. F. M., Compêndio histórico da congregação da Terceira Ordem de Portugal..., Lisboa, Oficina de Simão Tadeu Ferreira, 1793, p. 212-217.
} 
Reino de Portugal, publicado em 1769. Mais tarde, outras províncias franciscanas adaptaram seus estudos ao Plano de Cenáculo e às diretrizes dos estatutos reformados da Universidade de Coimbra, de 1772. Assim, em 1774 foram publicados novos planos de estudos para os religiosos da Ordem Terceira Regular e, em 1776, para os franciscanos das províncias de Portugal, da Piedade, da Soledade e da Imaculada Conceição do Rio de Janeiro. ${ }^{35}$

Devido à direta influência desempenhada por este último documento na formação dos frades menores fluminenses - apenas Rodovalho realizou sua formação filosófica e teológica antes da reforma dos novos estatutos -, alguns pontos merecem particular análise. Os estudos menores contemplavam três cadeiras, quais sejam, a Retórica, o Grego e o Hebraico, enquanto os estudos maiores se dividiam em Filosofia, História Eclesiástica, Teologia Dogmática, Teologia Moral e Teologia Exegética. Com relação ao ensino da Retórica, que interessa mais de perto, os Estatutos lamentavam o declínio da arte oratória desde o tempo dos antigos, "até ficar tão denegrida e afeada, que apenas se viam dela mais que alguns Tropos e Figuras [...] amontoados". No que tange à exegética, o estudo da Hermenêutica Sagrada deveria capacitar os alunos "das regras necessárias, tanto para a interpretação da mesma Escritura, como para a conciliação dos Textos, que nela parecem entre si opostos". No documento em pauta, torna-se flagrante o ideário do pombalismo, condenando-se, em diversos momentos, a inutilidade do "Método Peripatético Escolástico". No que tange ao estudo da Filosofia, é importante destacar a abertura para o empirismo, em sintonia com os estatutos reformados da universidade, ao ser reservado o terceiro ano dos estudos filosóficos à Geometria, à História Natural e à Física Experimental. ${ }^{36}$

Quanto ao tratado de oratória cuja primeira parte foi publicada em 1776, Cenáculo sustentava uma atitude antiescolástica mais moderada, criticando tanto os excessos da parenética seiscentista quanto o exagero contido nas imitações oriun-

\footnotetext{
${ }^{35}$ Antonio Alberto de Andrade, Vernei e a cultura do seu tempo, Coimbra, Imprensa da Universidade, 1966, p. 386-396. Ver, também, Jacques Marcadé, Frei Manuel do cenáculo Vilas Boas, Évêque de Beja, Archevêque d'Evora (1770-1814), Paris, Centro Cultural Português/Fundação Calouste Gulbenkian, 1978, p. 11-48.

${ }^{36}$ Estatutos para os estudos da Província de Nossa Senhora da Conceição do Rio de Janeiro, ordenados segundo as disposições dos Estatutos da Nova Universidade, Lisboa, Régia Oficina Tipográfica, 1776, p. 3-21. As citações foram atualizadas para o português corrente, mas os títulos das obras permaneceram no original.
} 
das da França. É mesmo a favor do uso comedido de metáforas e alegorias nos sermões. ${ }^{37}$ Os pregadores franciscanos da província da Imaculada Conceição do Rio de Janeiro foram afetados pelas contínuas mudanças nos padrões da oratória sagrada. Duran assinala a influência exercida pelos sermões de Bossuet sobre os oradores sagrados do período joanino. ${ }^{38} \mathrm{~A}$ tradução do exórdio em latim e a economia das citações diretas da Vulgata, que caracterizam os sermões de Sampaio, São Carlos, Monte Alverne e outros franciscanos do período, podem ser fatores a indicar o afastamento do estilo concionatório seiscentista, nos quais era frequente $\mathrm{o}$ uso de extensas citações latinas, e a aproximação diante dos modelos da parenética francesa, em que a Vulgata era vertida para o vernáculo. ${ }^{39} \mathrm{~A}$ influência de autores franceses transcendeu a eloquência sagrada. Um marco para a sensibilidade religiosa do período, o Génie du christianisme, de Chateaubriand (1802), aparece citado na oração fúnebre que Monte Alverne recitou em 1816 na catedral de São Paulo, dedicada à rainha Dona Maria $\mathrm{I}^{40} \mathrm{~A}$ produção das Luzes foi também referida por Monte Alverne em diferentes momentos: a Histoire des Indes, de Raynal, uma referência abreviada à obra mais famosa do abade francês, publicada em 1770, e L'esprit des lois, de Montesquieu (1748). ${ }^{41}$ Monte Alverne reconheceu o significado que assumiu para a sua formação a leitura dos autores franceses, no "Discurso preliminar" que elaborou em 1853 para as Obras oratórias:

A Metrópole não queria homens sábios nas suas colônias: era à custa de esforços inauditos que os brasileiros podiam distinguir-se. Restava um meio fácil de promo-

\footnotetext{
${ }^{37}$ Aníbal Pinto de Castro, Retórica e teorização literária em Portugal, op. cit., p. 575-584.

${ }^{38}$ Maria Renata da Cruz Duran, Ecos do púlpito, op. cit., p. 111.

${ }^{39}$ Aníbal Pinto de Castro, Retórica e teorização literária em Portugal, cit., p. 541. O autor esclarece que não se aplicou na França uma cláusula do Concílio de Trento segundo a qual "a Bíblia não podia verter-se para vulgar, enquanto as restantes nações católicas a observavam escrupulosamente". O emprego de citações da Vulgata assumia o valor teológico de prova nos sermões. A respeito da difusão de uma "French manner" nos sermões portugueses setecentistas, ver, também, Ferdinand Azevedo, S. J., "Teodoro de Almeida: a religious orator of the Portuguese enlightenment", Luso-Brazilian Review, v. 16, n. 2, Wisconsin, 1979, p. 239-247. Ao afastar-se da parenética barroca marcada pelo uso da alegoria e aproximando-se de um raciocínio lógico "geométrico", o oratoriano Teodoro de Almeida parecia particularmente empenhado em compatibilizar o cristianismo com o Iluminismo.

${ }^{40}$ Frei Francisco do Monte Alverne, O. F. M., Obras oratórias, Rio de Janeiro, Paris, Garnier, [s.d.], v. 2 , p. 361 .

${ }^{41}$ Ibidem, p. 275 e 278. As duas menções aparecem na oração em ação de graças pela elevação do Brasil a reino, pregada na vila de Itu em 1816.
} 
ver o nosso adiantamento, o estudo da língua francesa: porém ainda em 1807 não havia no Rio de Janeiro um professor público desta língua. Foi para mim um triunfo, digno de igualar-se aos trabalhos de Hércules, aprender sem mestre, e sem o socorro da gramática, este idioma tão rico de escritores eminentes. Entregando-se à cultura da eloquência, o jovem orador brasileiro era condenado a ficar na obscuridade, estudando os oradores portugueses, cujos sermonários eram comuns entre nós; ou a procurar na leitura dos pregadores franceses as inspirações, de que carecia para ilustrar o seu espírito, e abrilhantar seus discursos. ${ }^{42}$

Os 14 sermões que serão alvo de estudo foram elaborados pelos cinco pregadores franciscanos já mencionados. Podem ser divididos em dois gêneros, quais sejam, o gratulatório, em que se objetivava "agradecer a Deus e aos santos algum benefício recebido", e o deprecatório, que visava a "solicitar do Céu favores cuja obtenção os oradores estavam convictos de exceder os meios humanos". ${ }^{43}$ Pertencem ao primeiro grupo todas as orações em ação de graças e os panegíricos dedicados a santos e autoridades. Do segundo grupo, fazem parte as inúmeras orações fúnebres. Ao ordenar os sermões a partir de uma sequência cronológica, verifica-se que sua realização coincide muitas vezes com as efemérides da monarquia de Bragança. Essa coincidência não era casual, podendo-se analisar o sermão como um texto integrante de uma composição maior, os fastos políticos da realeza, em cuja montagem figuravam também a ornamentação das ruas e fachadas, a música, os trajes de gala, o apuro do cerimonial, as luminárias, os fogos de artifício e as salvas de navios e fortalezas, conforme se pode apurar na obra do principal cronista do período. ${ }^{44}$

Como ocorria no período da Restauração, a continuidade e a estabilidade do regime monárquico continuavam a ser as maiores preocupações dos oradores. Se o referente político é visível nas peças de oratória sagrada, ele aparece, não obstante, transfigurado pela linguagem religiosa, utilizada segundo as regras da hermenêutica teológica. Pensando nos propósitos políticos dos sermões, é possível distinguir temas que servem como fio condutor para as obras dos pregadores franciscanos. Nos primeiros anos de instalação da Corte no Rio de Janeiro, a ameaça representada pelos franceses marcou a conjuntura política do período,

\footnotetext{
${ }^{42}$ Frei Francisco do Monte Alverne, O. F. M., Obras oratórias, op. cit., v. 1, p. XII.

${ }^{43}$ João Francisco Marques, A parenética portuguesa e a Restauração, op. cit., p. 98; grifo nosso.

${ }^{44}$ Luiz Gonçalves dos Santos (Padre Perereca), Memórias para servir à história do reino do Brasil, ed. anotada por Francisco de Noronha Santos, Belo Horizonte, Itatiaia; São Paulo, Edusp, 1981, 2 v.
} 
encontrando-se representada em alguns sermões. A esse respeito, talvez o mais contundente tenha sido o que frei Joaquim de São José pregou no fim de 1808. Depois de tratar da "abominável França", usou as seguintes palavras para (des) qualificar Napoleão:

[que] à testa desse povo já depravado, aparecesse o homem mais perverso que tem havido; que sobre o trono, que a Irreligião e a iniquidade haviam fabricado, se sentasse o homem mais iníquo, que o mundo viu; o... não, não quero profanar o Santuário; jamais pronunciarei o seu abominável nome: o grande, o grande ímpio, eis aqui o seu caráter, este o seu apelido. Esse monstro de maldades e delitos; esse iníquo entre os mesmos iníquos, esse perverso entre os mais perversos; enfim, essa fera indômita, opróbio da humana espécie, desonra da racionabilidade, que sufocando todos os sentimentos mais naturais ao coração do homem, pervertendo todas as afeições de que é suscetível a alma, pisando os deveres mais santos e impreteríveis, as relações mais augustas e respeitáveis, tem levado a dissolução e o estrago aos Impérios, aos Reinos, às Cidades, às Nações, e às Famílias. Tal é aquele, que tem assassinado a Europa inteira; que tem desorganizado o mundo político; que empreendeu fazer escravos todos os povos. ${ }^{45}$

Outro exemplo pode ser apurado no sermão que frei Francisco de São Carlos pregou no primeiro aniversário de permanência da Corte no território fluminense. Napoleão também não se encontra nominalmente mencionado no texto, embora o orador faça inúmeras alusões indiretas ao imperador dos franceses, como "Invasor", "lobo da fábula", "Rei dos novos Godos" e "Usurpador". ${ }^{46}$ Em 1812, na oração fúnebre dedicada ao príncipe Dom Pedro Carlos de Bourbon e Bragança, frei Francisco de Sampaio resignava-se diante da vontade divina, que chamava para si aquele nobre aliado, enquanto outro Bourbon flagelava a Europa: "Oh morte quando fartarás a sede do sangue dos Bourbons? Até nos países mais remotos tu vens feri-los; vivem os Tiranos, vivem os flagelos da humanidade; tu voas com eles por cima das ruínas dos Impérios e dos Tronos e só a virtude

\footnotetext{
${ }^{45}$ Frei Joaquim de São José, O. F. M., Sermão de acção de graças pela feliz restauração de Reino de Portugal pregado em 21 de dezembro de 1808 na Real Capela do Rio de Janeiro [...]. Por [...] padre da Província de Nossa Senhora da Arrábida, Pregador Régio, Rio de Janeiro, 1809, na Impressão Régia, por Ordem de S. A. R., p. 10-11.

${ }^{46}$ Frei Francisco de São Carlos, O. F. M., Oração de acção de graças, recitada no dia 7 de março de 1809 na Cappela Real, dia aniversário da feliz chegada de Sua Alteza Real a esta cidade, pelo [...], Rio de Janeiro, 1809, na Impressão Régia, com Licença de S.A.R, p. 5 e 7.
} 
cai debaixo de teus golpes?" ${ }^{27} \mathrm{Na}$ oração fúnebre que dedicou em 1816 à rainha Dona Maria I, o "Anjo Exterminador" que consta no texto faz referência a Napoleão. ${ }^{48}$ É significativo assinalar que a mesma denominação foi aplicada por Monte Alverne a Átila. ${ }^{49}$ Em ambos os casos, os autores aplicaram o método tipológico, na medida em que relacionam tais eventos políticos a passagens dos livros do Êxodo e do Apocalipse.

Conforme já salientado na análise da professora Lúcia Neves, Napoleão e os franceses foram representados no discurso dos partidários da Casa de Bragança como encarnações do mal. No polo oposto, completando um sistema simbólico maniqueísta, os portugueses figuravam como novo povo eleito, conduzidos pela gloriosa e sagrada monarquia bragantina. Os sermões já aludidos atestam em inúmeras passagens o argumento exposto. Dentre os pregadores mencionados, São Carlos utilizou com mais frequência a retórica tipológica na construção da sacralidade da monarquia lusitana. Assim, no sermão de 1809, considerava o príncipe regente Dom João "o Davi de nossos dias, cujo único prazer é o culto, e o triunfo da Arca Santa”. Em seguida, após contrastar a dissolução de inúmeras cortes europeias com a sobrevivência da dinastia de Bragança, aproximava o príncipe regente de outro patriarca do Antigo Testamento: "Ó Deus, vós animais o Príncipe de Portugal, pois que é o Noé, que se salva no meio de tão grande dilúvio." ${ }^{50} \mathrm{Na}$ oração fúnebre pregada em 1816 na catedral de São Paulo, Monte Alverne assinalava que a rainha Dona Maria I era "herdeira da piedade de Davi e da magnificência de Salomão".${ }^{51}$ Em outra oração fúnebre à rainha, pregada no

\footnotetext{
${ }^{47}$ Frei Francisco de São Paio, O. F. M., Oração fúnebre, que nas Exéquias mandadas fazer por Sua Alteza Real, o príncipe regente Nosso Senhor, ao Sereníssimo Senhor D. Pedro Carlos de Bourbon e Bragança, Infante de Hespanha, recitou na Capela Real [...], Rio de Janeiro, na Impressão Régia, 1812, por Ordem de Sua Alteza Real, p. 22.

${ }^{48}$ Frei Francisco de São Carlos, O. F. M., Oração fúnebre recitada na Igreja da Cruz da Corte do Rio de Janeiro, nas exéquias da senhora D. Maria I. Rainha Fidelíssima do Reino Unido de Portugal, do Brazil e Algarves. Por [...], Rio de Janeiro, na Impressão Régia, 1816, com Licença da Mesa do Desembargo do Paço, p. 19.

${ }^{49}$ Frei Francisco do Monte Alverne, O. F. M., "Sermão pregado no dia 12 de setembro de 1813, aniversário da sagração do Excelentíssimo e Reverendíssimo senhor D. Mateus de Abreu Pereira, bispo de São Paulo". In: Obras oratórias, op. cit., v. 2, p. 262.

${ }^{50}$ Frei Francisco de São Carlos, O. F. M., Oração de acção de graças, op. cit., p. 6 e 13.

${ }^{51}$ Frei Francisco do Monte Alverne, O. F. M., "Oração fúnebre de Sua Majestade Fidelíssima D. Maria I, Rainha de Portugal, Brasil e Algarves, recitada na Catedral de São Paulo no dia 26 de junho de 1816”. In: Obras oratórias, op. cit., v. 2, p. 366.
} 
Rio de Janeiro em 1816, São Carlos exclamou, ao lembrar seu casamento com um consorte da própria Casa de Bragança: "Nova Raquel formosa, outro Jacó devia marchar do país de Canaã para ser o possuidor de seu coração. Eu digo tudo, Senhores, seu Sereníssimo Tio foi o único Venturoso, que mereceu sua mão núbil e virginal." 52 É interessante verificar que, no contexto da Restauração de 1640, o rei encoberto Dom João IV fora também comparado a Noé. Por sua vez, a santa portuguesa Isabel, cuja canonização ocorrida no século XVII alimentou também a atmosfera de exaltação patriótica, foi aproximada da figura bíblica de Raquel, esposa de Jacó. ${ }^{53}$ Talvez seja exagero considerar como plágio tais coincidências. O uso das tipologias do Antigo Testamento implicava o domínio de um corpo comum de referências, aprendido pelos religiosos nos cursos de retórica.

O tema da perenidade da monarquia lusitana em meio a uma conjuntura revolucionária deve merecer também atenção. É significativo perceber que aparece enunciado com toda a clareza na oração fúnebre de São Carlos, produzida no instante em que falecia a titular do trono. A essa altura, em 1816, o pânico diante de Napoleão já se atenuara. São Carlos entrelaça engenhosamente o referido fato à morte da soberana, fazendo um uso digno de nota do conceito predicável:

Enfim, que o Tirano eclipsara-se, que tornara a entrar no pó, donde saíra, e que toda a Europa ficava em paz. Parece que, assim (perdoai a expressão, Senhores, se vos escandaliza), parece que, assim como foi necessário que todo o mundo se apaziguasse para nascer o seu Redentor para a terra; foi também necessário que se apaziguasse toda Europa para ela nascer para o Céu. Toto orbe pacato. Ela viu formar-se e acabar-se a revolução no seu Reinado, sempre intacta no sagrado de sua pessoa; assim como a Santa Igreja vê nascer e morrer em seu seio as heresias, sempre a mesma e ilesa na pureza dos seus dogmas. ${ }^{54}$

No sermão que frei Rodovalho elaborou em 1793 por ocasião do nascimento da princesa da Beira, a existência do trono era vista como garantia do amor da pátria e da família, dos cargos e dos títulos públicos, do comércio, da agricultura, das artes e das ciências, assim como do culto divino. ${ }^{55}$ Em defesa dos princí-

\footnotetext{
${ }^{52}$ Frei Francisco de São Carlos, O. F. M., Oração fúnebre recitada na Igreja da Cruz, op. cit., p. 9.

${ }^{53}$ João Francisco Marques, A parenética portuguesa e a Restauração, op. cit., v. 1, p. 150-151.

${ }^{54}$ Frei Francisco de São Carlos, O. F. M., Oração fúnebre recitada na Igreja da Cruz, op. cit., p. 22-23.

${ }^{55}$ Frei Antônio de Santa Úrsula Rodovalho, O. F. M., Oração de acção de graças, que pelo muito feliz e augusto nascimento da sereníssima senhora D. Maria Thereza Muito Alta e Muito Poderoza Princeza da Beira recitou na Catedral do Rio de Janeiro no dia 19 de dezembro de 1793, e oferece
} 
pios dinásticos de sucessão e da ordem hierárquica do Antigo Regime, o referido pregador condenava as teses de igualdade dos homens e do afastamento destes diante do plano da criação, difundidas por "filósofos deste século":

Sabemos, que os homens vêm das mãos do seu autor para os braços da sociedade. Dentro dela o estado de igualdade universal é mais que metafísico.

O objeto desta ideia é o homem primitivo, mas não o homem social. Se os quereis iguais, deveis separá-los contra todos os seus destinos, aniquilando suas mui nobres faculdades. Se nascem livres por natureza, também a natureza lhes impõe deveres. A liberdade, sendo necessária para fazer suas ações dignas de louvor, não os autoriza contra Deus... ${ }^{56}$

Em contraste com a bonança e a estabilidade do regime monárquico, situava-se a torrente revolucionária procedente da França. Essa ideia aparece representada em uma oração fúnebre pregada por Francisco de Sampaio em 1817: "a Europa acabava de ouvir o formidável estampido desse vulcão, que rebentara na França sepultando em seus abismos o Trono de Henrique IV e de Luís IX" ${ }^{57}$ Sem esgotar a variedade das representações da revolução no sermonário franciscano, figura outro exemplo expressivo no texto de frei Joaquim de São José:

Arrebatada de um espírito maligno [frenético?], e revolucionário, avultada de uma convulsão espantosa e horrível, essa Nação, que blasonava de sábia, ilustrada e polida, essa Nação, que desde agora deve ser para sempre a todos os viventes e a todas as gerações execrável, e cuja memória deve ser para sempre maldita: a França, quem tal diria! A abominável França apareceu como do centro do horroroso abismo, atacando, destruindo e assolando tudo no meio da Europa sossegada e tranquila. ${ }^{58}$

O regular nascimento de príncipes de sangue real tornava-se uma condição necessária para garantir a estabilidade e a continuidade do trono. Portugal pare-

à mesma Senhora no ano de 1809 Fr. [...] Pregador Régio, Rio de Janeiro, 1809, na Régia Officina Typografica, p. 18.

${ }^{56}$ Ibidem, p. 21.

${ }^{57}$ Frei Francisco de São Paio, O. F. M., Oração fúnebre do Emminentíssimo, e Reverendíssimo Senhor D. Lourenço Caleppi dos Condes do mesmo título, arcebispo de Nizibi, Núncio Apostólico de Sua Santidade o Santíssimo padre Pio VII. No Reino Unido de Portugal, do Brazil e dos Algarves, Cavalleiro da Ordem da Malta, Gram-Cruz da Ordem da Torre e Espada e Cardeal da Santa Igreja. Recitada em Prezença do seu corpo no Convento de Santo Antônio por [...] Pregador Régio, Rio de Janeiro, na Impressão Régia, 1817, com Licença da Meza do Desembargo do Paço, p. 14.

${ }^{58}$ Frei Joaquim de São José, O. F. M., Sermão de acção de graças, op. cit., p. 9. 
cia abençoado pela providência divina, que não deixava faltar herdeiros válidos para a sucessão da Coroa, particularmente do gênero feminino. Os sermões pregados por Rodovalho (1793) e Monte Alverne (1819) por ocasião do nascimento das princesas da Beira ilustram tal argumento. ${ }^{59}$ De acordo com o primeiro pregador, quando a sucessão era incerta, como no caso de vários pretendentes disputarem o trono, a monarquia corria um risco iminente: "alianças antiquíssimas, confundidas por tantos modos entre si, longe de apresentarem uma preferência indisputável, excitariam divisões populares, que semelhantes a um incêndio devorariam Cidades". ${ }^{60}$ No período filipino, a Coroa portuguesa já fora vitimada pelo flagelo da ausência de sucessão, como assinalava São Carlos: "Lisboa, vós o sabeis, gemeu sessenta anos na viuvez de seus Legítimos Soberanos.”61

Ligando-se simultaneamente à questão sucessória e à sacralidade da monarquia, aparece na obra de alguns pregadores o tema da linhagem de princesas e rainhas santas que teria caracterizado o trono lusitano. Discorrendo sobre a infância da futura rainha Dona Maria I, São Carlos narrava que a devoção da soberana fora alimentada no palácio paterno, onde encontrou "uma Sociedade de Profetas, Irmãs Virgens [...]. De sorte que se podia aplicar à Casa Real de Bragança o que os Padres do Concílio de Calcedônia aplicavam ao palácio do imperador Marciano: que parecia antes um mosteiro de Religiosos que residência de Soberanos”. ${ }^{62}$ Aplicando o conceito predicável e a retórica tipológica, São Carlos conclui que a santidade da rainha Dona Maria I era comparativamente maior que a dos monges e dos pobres, na medida em que se desenvolveu em um meio que não era propício à prática das virtudes sagradas:

Salvar-se no meio dos obstáculos da salvação: que as mesas lautas não enervem os jejuns; que os cantos moles e teatrais não desafiem os brios da impudicícia; que os lei-

\footnotetext{
${ }^{59}$ Frei Francisco de Monte Alverne, O. F. M., "Oração no dia 5 de outubro de 1819 na solene ação de graças que El-rei o senhor D. João VI fez celebrar no Convento do Senhor Bom Jesus da Ilha, por o feliz nascimento da Sereníssima Princesa da Beira D. Maria da Glória, depois D. Maria II, rainha de Portugal e dos Algarves". In: Obras oratórias, op. cit., v. 2, p. 345-354.

${ }^{60}$ Frei Antônio de Santa Úrsula Rodovalho, O. F. M., Oração de acção de graças, op. cit., p. 17.

${ }^{61}$ Frei Francisco de São Carlos, O. F. M. A El-rei Nosso Senhor O. D. C. O Senado da Câmara desta Corte a Oração Sagrada, que na solemne acção de graças pelo muito feliz e augusto nascimento da Sereníssima Senhora D. Maria da Glória Princeza da Beira, celebrada na Igreja de S. Francisco de Paula pelo mesmo Senado da Câmara, recitou no dia 12 de maio o [...], Rio de Janeiro, na Impressão Régia, 1819, com Licença de Sua Magestade, p. 13.

${ }^{62}$ Frei Francisco de São Carlos, O. F. M., Oração fúnebre recitada na Igreja da Cruz, op. cit., p. 7-8.
} 
tos brandos não convidem à moleza e à preguiça: que o oiro e a púrpura não nutram o luxo: Que Davi arrancado do meio dos rebanhos, à testa de Israel não se esqueça de sua primeira fortuna e só cuide em fazer reinar em seu trono o DEUS por quem ele reina [...]. Que uma Grande Soberana, Senhora de grandes Estados em todas as partes do mundo, à testa de uma Nação aguerrida, espiritual, industriosa, assentada em um dos mais célebres Tronos da Europa, não se deixe enfatuar pelos encantos da fortuna e condição; que busque e adore a verdade, quando a lisonja é tão doce à corrupção da natureza; que ame e exercite a mortificação cristã. ${ }^{63}$

A virtude modelar não caracterizou apenas a soberana da Casa de Bragança. Era, antes, uma característica desenvolvida há muito pela realeza em Portugal. À estirpe das "Santas Princesas Lusitanas" pertenciam, segundo São Carlos, Sancha, Mafalda e Joana. ${ }^{64}$ Frei Rodovalho mencionou também essas três nobres mulheres - que já estavam no "Catálogo dos santos" - e outras "que tem servido de ornamento à Igreja, de honra a muitos cetros, e de utilidade a muitos povos". ${ }^{65}$ Monte Alverne ligou a recém-nascida princesa da Beira ao "ardor santo das Mafalda e das Isabel". ${ }^{66}$ Essa ênfase particular dos pregadores na linhagem sagrada da monarquia talvez fosse uma necessidade em um contexto marcado pelo questionamento das bases do poder dinástico.

Um tema central para a parenética seráfica do período joanino é constituído pela missão providencial do povo português e da monarquia lusitana. O caráter sagrado desta tinha se manifestado no momento em que fora instituída por Dom Afonso Henriques em Ourique, conforme indicava Rodovalho, retomando uma imagem cara ao movimento da Restauração:

Feliz monarquia portuguesa, que, depois de receber, como da mão de Deus, o seu primeiro rei, depois de o ver exaltado por uma escolha singular da Providência, animado de promessas divinas, que ainda se vão cumprindo, vitorioso de seus inimigos, conquistador acérrimo de seu novo império, vem a lograr na pessoa do muito alto e muito poderoso príncipe, que o seu tem destinado para subir ao trono, a mais firme segurança da sua perpétua felicidade. ${ }^{67}$

\footnotetext{
${ }^{63}$ Frei Francisco de São Carlos, O. F. M., Oração fúnebre recitada na Igreja da Cruz, op. cit., p. 18; maiúsculas em "Deus" do autor.

${ }^{64}$ Ibidem, p. 20-21.

${ }^{65}$ Frei Antônio de Santa Úrsula Rodovalho, O. F. M., Oração de acção de graças, op. cit., p. 11.

${ }^{66}$ Frei Francisco de Monte Alverne, O. F. M., "Oração no dia 5 de outubro de 1819 na solene ação de graças...", op. cit., v. 2, p. 353.

${ }^{67}$ Frei Antônio de Santa Úrsula Rodovalho, O. F. M., Oração de acção de graças, op. cit., p. 2.
} 
São Carlos, em um sermão pregado em 1819, associa as origens míticas da monarquia lusitana às vitórias alcançadas sobre diversos inimigos: "nascida entre os troféus do Campo de Ourique, jamais degenerou de sua origem". Os portugueses "apenas chegam, eis que logo mostram que o sangue dos heróis de Aljubarrota, do Ameixial, dos Montes Claros e ultimamente de Vimeiro e Badajoz ainda circula nas suas veias" ${ }^{\prime 6}$ Os feitos dos portugueses contra as tropas de Napoleão foram assim inseridos em uma narrativa patriótica, que ressaltava as glórias militares lusitanas em momentos de crise política, como Aljubarrota (1383) e a guerra da Restauração (1640-1668). Os feitos da expansão marítima constituem outro episódio político valorizado pelos pregadores franciscanos. São Carlos traça uma linha de continuidade entre as glórias do século dos descobrimentos e as vitórias recentemente obtidas contra os franceses:

Agora, que organizados os nossos exércitos, os Portugueses despertavam do seu letargo, e começavam a mostrar que ainda não tinham degenerado dos Pachecos, dos Albuquerques e dos Castros. Nem daqueles atrevidos argonautas, que arrancaram das mãos do gigante das tormentas as chaves que fechavam as portas da Aurora. E que o vestido de glória, que os trajava no século 16 , ainda se não tinha rompido no século $19 .{ }^{69}$

Nessa visão teleológica do processo histórico, em que Portugal aparece sempre protegido pela divina providência, Monte Alverne valorizava mais os feitos políticos ocorridos no continente americano, como a Restauração de Pernambuco. O frade franciscano chega inclusive a opor a efemeridade do brilho do império oriental em relação ao Novo Mundo desbravado pelos lusitanos: "Gama deu a sua pátria um comércio, que lhe seria pouco proveitoso, que teria mesmo sido prejudicial à Europa, porque engoliria afinal todo o seu ouro: Cabral, com seu descobrimento, alimentou a indústria de Portugal e da Europa, com a extração e consumo de suas mercadorias." ${ }^{70}$

Os benefícios e sucessos obtidos pelos lusitanos, argumentavam os pregadores, não poderiam ser alcançados a não ser por intermédio de uma particular

${ }^{68}$ Frei Francisco de São Carlos, O. F. M., A El-rei Nosso Senhor O. D. C. O Senado da Câmara desta Corte a Oração Sagrada, op. cit., p. 18.

${ }^{69}$ Frei Francisco de São Carlos, O. F. M., Oração fúnebre recitada na Igreja da Cruz, op. cit., p. 22.

${ }^{70}$ Frei Francisco do Monte Alverne, O. F. M., "Oração em ação de graças por a elevação do Brasil a reino pregada na vila de Itu, província de São Paulo, no dia 4 de fevereiro”. In: Obras oratórias, op. cit., v. 2, p. 277. 
eleição divina. De outra forma, como explicar que um povo "sem meios, sem socorros, sem abundância de braços, com poucos recursos" tivesse causado admiração em todo o mundo ? $^{71}$ Torna-se significativo constatar, na discussão do tema da ação da providência divina na História, a existência de mais uma continuidade entre os períodos pós-filipino e joanino. Neste último, frei Joaquim de São José foi um dos que acrescentaram mais detalhes ao assunto:

Como, como sem a Providência se poderão explicar esses fatos extraordinários neles descritos; fatos extraordinários e grandes, que surpreendem e arrebatam somente lidos? Como pode uma Nação pequena, cercada de bárbaros, ou para melhor dizer, cativa, exterminar até o último dos opressores, vencer os seus inimigos, conter os seus aliados, tornar-se independente e livre, fazer-se respeitável, senão temível, aos grandes povos e Nações vizinhas? Por que oculto princípio um Reino quase recémnascido, pequeno, e na mais pequena parte do mundo conhecido se elevou, como em um momento, a tanta glória, que avassalasse ao seu Império o mais interessante da África, o mais rico da Ásia, e o mais precioso da América? ${ }^{72}$

Entre as representações que a parenética franciscana do período veiculou acerca da monarquia e da sociedade de ordens encontram-se as imagens do corpo místico. A visão alegórica da monarquia como um corpo humano constituiu um tópico presente nos tratados jurídicos e teológicos desde a Baixa Idade Média. O sentido predominante transmitido por essa imagem era o da união orgânica entre súditos e soberanos, de modo que "os súditos se encontram incorporados no rei, e o rei nos súditos" ${ }^{73}$ No período joanino, a representação corporativa e tradicional da monarquia foi expressa, entre outros, por Francisco Antônio Novaes Campos e Antônio Ribeiro dos Santos. Nos escritos desses autores, o uso da mencionada alegoria tem o efeito de limitar os poderes do soberano. ${ }^{74}$ Em São Carlos, além dos sentidos tradicionais da imagem do corpo místico, transparece

\footnotetext{
${ }^{71}$ Frei Francisco de São Carlos, O. F. M., A El-rei Nosso Senhor O. D. C. O Senado da Câmara desta Corte a Oração Sagrada, op. cit., p. 17-18.

${ }^{72}$ Frei Joaquim de São José, O. F. M., Sermão de acção de graças, op. cit., p. 8.

${ }^{73}$ Ernst H. Kantorowicz, Los dos cuerpos del rey: um estudio de teología política medieval, trad., Madri, Alianza, 1985, p. 215. Ver, também, William de Souza Martins, "Encontros com a história cultural, a partir do estudo das festas, das ordens religiosas e da santidade feminina no Antigo Regime”. In: William Martins \& Gisele Sanglard (orgs.), História cultural: ensaios sobre linguagens, identidades e práticas de poder, Rio de Janeiro, Apicuri, 2010, p. 25-34.

${ }^{74}$ Iara Lis Carvalho Souza, Pátria coroada, op. cit., p. 21-38.
} 
também uma identificação entre os vínculos políticos e os de sangue, revelando mais uma permanência em face do contexto da Restauração:

O Rei natural olha para seus vassalos, como seus filhos: e os vassalos para o Rei, como a seu Senhor e seu compatriota. A multidão de braços que o cerca toda concorre ou para sustentar-lhe o trono ou para perpetuar-lhe a glória. Então o estado é um corpo vivo e animado, cujo coração, que é o Rei, leva até as extremidades a sístole e a diástole do sangue vital da Sociedade. ${ }^{75}$

Rodovalho forneceu ao tema um desenvolvimento ainda mais completo. No uso que faz da alegoria, fica patente como esta funcionava de modo a naturalizar os vínculos de submissão política. De modo inverso, as ameaças à harmonia garantida pelo regime monárquico e pela sociedade corporativa são vistas como aberrações contrárias à ordem da criação:

Quais são, dizei-me, os maiores bens, que podeis esperar da Monarquia? São muitos; e dizeis bem; porque são todos estes, que ao presente logramos, e eles dependem da Sucessão do Trono. Sendo dali, donde o grande corpo de uma Nação recebe a cabeça, dali é também, que recebe a vida, o movimento, a atividade: dali as sábias Providências, os socorros mais prontos, e importantes para conservar e defender este corpo: dali a ordem, a harmonia, que deve reinar em todos os seus membros; os mútuos auxílios, que se devem prestar...

Qualquer de nós traz em seu próprio corpo a perfeita imagem de uma Monarquia. Temo-la também na alma; porém Deus parece que formou a do corpo, para mostrarvos agora quanto padeceria vosso corpo, se os pés, que o sustentam sobre a terra, pretendessem colocar-se mais alto; se outros membros quisessem subir ao lugar dos braços; ou se algum destes dissesse à cabeça: oh lá! eu sou igual a ti, presidirei em teu lugar. Desprezemos este monstro... ${ }^{76}$

Um dos fundamentos da sociedade do Antigo Regime, a união entre o trono e o altar, figurava em lugar de destaque nos sermões dos oradores franciscanos. No contexto em pauta, tais vínculos encontravam-se abalados, por conta da difusão do ideário revolucionário e da execução de políticas regalistas por parte das autoridades monárquicas. $\mathrm{Na}$ oração fúnebre que dedicou ao núncio apostólico Dom

\footnotetext{
${ }^{75}$ Frei Francisco de São Carlos, O. F. M., A El-rei Nosso Senhor O. D. C. O Senado da Câmara desta Corte a Oração Sagrada, cit., p. 15-16. Segundo João Francisco Marques, "o argumento do rei natural há de ser um dos leitmotiv das referências à legitimidade de D. João IV”. A parenética portuguesa e a Restauração, op. cit., v. 2, p. 15.

${ }^{76}$ Frei Antônio de Santa Úrsula Rodovalho, O. F. M., Oração de acção de graças, op. cit., p. 17-18.
} 
Lourenço Caleppi, falecido em 1816, Sampaio discorreu sobre as atividades exercidas pelo prelado em diversas partes da Europa, antes de assumir a nunciatura em Portugal. Assim, na Corte de Dom José II em Viena, "susteve a espada com que o Imperador feria as corporações Monásticas”. Em Florença, defendeu os interesses de Roma diante dos comissários do Diretório. ${ }^{77} \mathrm{Na}$ Corte joanina, a historiografia assinalou as tensões entre Caleppi e os tribunais da monarquia que tinham jurisdição sobre a esfera eclesiástica, assim como a defesa que empreendeu das congregações regulares contra os interesses da Coroa no fechamento dos noviciados e na incorporação dos bens de mão-morta. ${ }^{78}$ Longe de apontar os conflitos, os pregadores franciscanos viram no príncipe regente e na rainha modelos de perfeita devoção. Além do que já ficou dito antes, pode ser destacada a seguinte passagem de São Carlos, em que se torna patente o uso da retórica tipológica:

Um novo Davi, sem os defeitos do primeiro, príncipe, em quem ainda se não descobriu uma paixão dominante, fora da paixão do culto, e da glória de seu Deus: que habitaria sempre na casa do Senhor, como outro Samuel, se lhe permitissem os deveres da realeza [...]. Um príncipe a quem a perícia e perfeição dos ministros do Santuário, a pompa do mesmo Santuário, sua majestade, sua glória parece ser o único néctar generoso, que o embriaga, o único prato de delícias de seu apetite; que na assiduidade do templo, na paciência das suas solenidades diuturnas excede e espanta mesmo aqueles que em virtude de seu ministério deviam ser os primeiros, os mais assíduos, os mais constantes. ${ }^{79}$

Entre os pregadores do núcleo franciscano, Monte Alverne aparece como o mais distante dos padrões da retórica seiscentista e mais afinado com a renovação da oratória eclesiástica difundida a partir de meados do século XVIII. De modo geral, utiliza com mais parcimônia as alegorias, metáforas e tipologias construídas a partir da Bíblia e da tradição. Assim, enquanto a oração fúnebre que São Carlos dedicou à soberana concentra-se na perfeição das virtudes e da devoção, o sermão pregado por Monte Alverne na mesma oportunidade aponta para outros objetos de análise. Louvando a opulência comercial e a reconstrução de Lisboa por Dom José I, traça

\footnotetext{
${ }^{77}$ Frei Francisco de São Paio, O. F. M., Oração fúnebre do Emminentíssimo, e Reverendíssimo Senhor, op. cit., p. 13-16.

${ }^{78}$ Monsenhor Maurílio César de Lima, Lourenço Caleppi, primeiro núncio no Brasil (1808-1816): segundo documentos do Arquivo Secreto Apostólico do Vaticano, Rio de Janeiro, IHGB, Conselho Federal de Cultura, 1977, p. 49, 61 e 127-129.

${ }^{79}$ Frei Francisco de São Carlos, O. F. M., A El-rei Nosso Senhor O. D. C. O Senado da Câmara desta Corte a Oração Sagrada, op. cit., p. 7-8.
} 
uma linha de continuidade entre esse soberano e Dona Maria I. Chega a comparar a rainha de Portugal a Catarina II da Rússia em matéria de realizações, entre as quais destacou no início do reinado a paz obtida com a Espanha. Aproximando o seu texto do círculo das Luzes, Monte Alverne realçou as seguintes transformações:

Lisboa foi no regime da senhora d. Maria I o que Sagres havia sido no reinado do senhor d. João II. Aulas de fortificação, escolas militares, uma nova academia real dos Guardas Marinhas elevam a mocidade portuguesa ao maior auge de instrução. Seus esforços para dar um novo realce à universidade de Coimbra, a fundação da Academia Real das Ciências completam a grinalda, com que se enfeita esta ilustrada soberana. Apareceram desde logo distintos naturalistas e astrônomos; intrépidos homens do mar; químicos e botânicos célebres; hábeis engenheiros e arquitetos. ${ }^{80}$

Se em Monte Alverne são perceptíveis algumas mudanças na parenética franciscana, transformações ainda mais substanciais aparecem no sermão publicado em 1821 por Sampaio. A linguagem empregada já não é a da Restauração de 1640, mas a da "Regeneração", a do vintismo. ${ }^{81}$ Assim, o autor preocupa-se em fundamentar as prerrogativas constitucionais dos cidadãos lusitanos "contra a feroz prepotência dos Tiranos", baseando-se para isso nos direitos de natureza e das gentes dos tratados de Wolff e Grotius. O uso de tipologias é empregado, mas desta vez para garantir a liberdade da nação. A esse respeito, consta uma citação que o autor retira do primeiro livro dos Macabeus:

Nós vamos de dia a dia a cair no último estado de desgraça, pertence-nos o direito de pôr em ordem os negócios do Reino; ofereçamos a este povo uma Constituição, para que viva segundo o espírito de suas Leis, e goze dos seus direitos, como antigamente, porquanto, pelo desprezo, que fizemos dos seus direitos, eles se enraiveceram, e nos fizeram todos estes males. ${ }^{82}$

${ }^{80}$ Frei Francisco do Monte Alverne, O. F. M., "Oração fúnebre de Sua Majestade Fidelíssima D. Maria I..., op. cit., p. 363.

${ }^{81}$ Lúcia Maria Bastos Pereira das Neves, Corcundas e constitucionais: a cultura política da Independência (1820-1822), Rio de Janeiro, Revan/Faperj, 2003; Lúcia Maria Bastos Pereira das Neves \& Humberto Fernandes Machado, O império do Brasil, Rio de Janeiro, Nova Fronteira, 1999, p. 65-84.

${ }^{82}$ Frei Francisco de Sampaio, O. F. M., Sermão de acção de graças que, em memória dos dias 24 de agosto e 15 de setembro de 1820, o Senado, os cidadãos do Rio de Janeiro solemnizarão no dia 15 de septembro, na Igreja de São Francisco de Paula, recitado por [...] Religiozo Franciscano da Província do Rio de Janeiro e Pregador Régio, Rio de Janeiro, 1821, na Typographia Nacional, p. 7. Comparar com a passagem de $1 \mathrm{Mc}, 6,57-59$ da Bíblia de Jerusalém: "Estamos enfraquecendo-nos dia por dia. Nossas provisões diminuem e o lugar que estamos sitiando é bem fortificado. Além 
Quanto ao estado da sociedade e da monarquia portuguesas, a avaliação de Sampaio aproxima-se do tom das críticas de Hipólito José da Costa e de outros ilustrados, afastando-se em definitivo do quadro delineado nos sermões anteriores e, mais diretamente, daquele delineado um pouco mais acima no sermão de Monte Alverne:

O que era a Nação Portuguesa, Snrs., antes das gloriosas épocas de 24 de Agosto e de 15 de Setembro? Um povo sem agricultura, sem comércio, sem navegação, sem riquezas, sem crédito público, entregue aos punhais de Ministros infames, que o sacrificaram à ambição dos Estrangeiros; à cuja vista só apresentava de um lado a formidável perspectiva desse Tribunal, vergonha do Evangelho, monumento insultador de um Deus de caridade. ${ }^{83}$

Por conseguinte, entre a retórica da Corte joanina e aquela que se desenvolvia no espaço da incipiente esfera pública que antecedeu a Independência, não deixou de haver uma mudança na linguagem política, para empregar os termos de Pocock. ${ }^{84}$ No entanto, em ambos os contextos, os diferentes atos de enunciação (paroles) continuaram apelando para tópicos discursivos semelhantes, para lugares-comuns familiares tanto aos oradores quanto à audiência que os escutava. Essa relativa continuidade se explica, dentro da produção oratória, pela utilização da hermenêutica teológica na elaboração dos sermões, em particular no desenvolvimento das alegorias e da tipologia. A relevância da parenética não pode ser diminuída no campo da produção do pensamento político no contexto enfocado. De fato, nas sociedades do Antigo Regime, a difusão oral da cultura predominava em relação à transmissão escrita. Por isso, adquiria a oratória sagrada uma repercussão muito mais ampla que os tratados políticos que justificavam a realeza e a sociedade de ordens; enquanto estes últimos confinavam-se à esfera muito reduzida dos letrados, essas peças retóricas eram apresentadas aos súditos portugueses, ao longo do período joanino, em concorridas ocasiões. Daí a importância e o alcance de que se revestem e que se buscou aqui realçar.

disso, os cuidados do reino aguardam-nos. Estendamos, pois, a mão direita a esta gente, fazendo as pazes com eles e com toda a sua nação. Vamos reconhecer-lhes o direito de viverem segundo as suas leis, como antes, já que é por causa dessas leis, que nós quisemos abolir, que eles se exasperaram e fizeram tudo isto."

${ }^{83}$ Ibidem, p. 19-20.

${ }^{84}$ J. G. A. Pocock, “O conceito de linguagem e o métier d'historien”. In: Linguagens do ideário político, São Paulo, Edusp, 2003, p. 63-82. 